To the Editors: I read the April issue of Worldview with double interest: as a Vietnamese and as a daughter of lawyer Tran Van Tuyen, a political detainee mentioned in "They Are Us, Were We Vietnamese" by Theodore Jacqueney.

My grief is so very much deeper since not only such a great number of Vietnamese people are being detained unjustly, but also among them are members of my own family: my father, confined under very inhuman conditions since June, 1975, without a single word on his whereabouts from the Hanoi Government; my brother, now in a labor camp somewhere in North Vietnam, according to some sources; my brotherin-law and a cousin (my father's nephew) in "reeducation" camps still awaiting their "graduation" after twenty months

The response from the Hanoi officials to the Forest appeal (discussed in "Fighting Among the Doves" by James Finn in the same issue of Worldview) with regard to violations of human rights in Vietnam is both a lie and an insult to the civilized world. If we have not seen the bloodbath it is because the Vietnamese Communists have a better means of killing: starvation, mental torture, and physical exhaustion.

I sincerely hope the two articles on Vietnam in Worldview will wake up those who still believe in the sweet language and promises of the Communists.

I would like to take this opportunity to express my deep appreciation and my gratitude to Ted Jacqueney, James Finn, and Richard Neuhaus and to all the people concerned about those who have suffered and are still suffering under the oppressive and undemocratic regimes in Vietnam.

Tran Thi Dam-Phuong

Haworth, N.J.

To the Editors: James Finn (" Fighting Among the Doves," April, 1977) seems unaware that we have American dissidents-thousands of them, mainly in Canada. They do not have the right to come into the USA even to visit their parents. Why is he so disregardful of their civil rights while sympathizing with dissidents in Communist countries?

Conditions in some of our veterans' hospitals are not good.

Moreover, we have more than
200,000 people imprisoned in the U.S. and our own prison conditions are bad. If we restored civil rights to our own dissidents in Canada and Sweden and reformed our prisons, our good example might be catching-and the human race would be safer.

Seattle, Wash.

Alice Franklin Bryant

James Finn Responds:

Ms. Bryant seems unaware that pages 28-29 of the April issue deal with American dissidents. Of course, there are remediable faults in this country. But must we rehearse that list each time we criticize massive abuses abroad? A dreary prospect.

\section{Good and Bad Dictatorships?}

To the Editors: I read with great interest "Christianity and Communism: The Dilemma of Dialogue," "Two Ways to Forget Vietnam," and "Latin America and the U.S.-That Special Relationship" in the April issue of Worldview. All those articles treat very up-to-date subjects, such as relations between developed and underdeveloped countries, perspectives on the increase of population tensions, disrespect for the rights, liberties, and guarantees stated in the Universal Declaration of Human Rights. As a Social Democrat, I consider these problems of major importance, since they are conditions for the via to a humanistic socialism by means of reforms and, therefore, in democracy and in freedom.

It is not fair to condemn the absence of democratic liberties in Latin America and to omit the disrespect for the more elementary rights of the human being in the Eastern countries, in Cambodia or in Ethiopia. In fact, there can be no division into good or bad dictatorships. All of them must be openly condemned by all democrats, who have the responsibility of contributing to man's liberation from every kind of oppression, wherever it exists and whatever might be the veil thrown over injustices, inequalities of opportunity, and every form of man's manipulation.

Within this point of view I cannot help expressing my total accordance with President Jimmy Carter's new foreign policy, which stands for funda- mental rights, liberties, and guarantees President Carter has been proving that he has a more progressive and a wiser character than his predecessors, his policy being truly appreciated in Portugal and, more widely speaking, all over Western Europe.

António Rebelo de Sousa

Member of Parliament

Social Democratic Party

Lisbon, Portugal

\section{AFSC}

To the Editors: The American Friends Service Committee has been taking a beating of late in the pages of Worldview. I am of the opinion also that criticism is in order; that the AFSC has not, in regard to Vietnam, lived up to the Quaker tradition of "speaking Truih to Power." However, I draw the line on the type of criticism in Abraham Martin Murray's "More on Updated Pacifism", ("A View of the World," April).

As all but a few realize, the Middle East conflict is an extremely complex problem and there is no individual or organization that can be credited with coming up with a perfectly satisfactory analysis of the problem and scenario for change. What is the terrible compromise of pacifist principles that the AFSC is guilty of? Urging Israel to negotiate with the PLO! Yet who else is there but the PLO if negotiations are to be at all meaningful and fruitful? Certainly no party in the Middle East can claim that its hands are not bloody. Perhaps if the AFSC had suggested that Israel bomb the PLO, the American Jewish Committee would not have been nearly as indignant about compromising of principles.

Their analogy of the Middle East conflict to the NAACP's confrontations with the $\mathrm{Ku}$ Klux Klan is but another example of the paerile tendency of Americans to simplify everything in terms of our domestic issues, as if the world is but our mirror image. Fairminded objectivity is not a hallmark of the American Jewish Congress, as I am sure most of your readers are aware. They are more than eager to practice the double standard in relation to Israel. You won't find them out beating the bushes about human rights violations in Israel, where they are known to occur, as in many other countries of the world. If the Palestinians silently vanished, the 